\title{
Corporate Social Responsibility And Tax Avoidance: Evidence From Korean Firms
}

\author{
SungJong Park, Anyang University, South Korea
}

\begin{abstract}
This study examines the relationship between corporate socially responsible (CSR) activities and tax avoidance using residual book-tax differences (BTD), year residual BTD and total BTD. Using a sample of 1,148 publicly listed Korean firms on Korean Stock Exchange (KSE) covering periods between 2004 and 2009 it finds that the firms with higher CSR activities are less likely to avoid taxes regardless which proxy of tax avoidance is used. This finding is confirmed with two stage least square (2SLS) method after accounting for endogeneity of CSR. It also tests how seven different CSR activities affect tax avoidance, and finds that social services, satisfaction of employees and contributions to economic development are negatively related to tax avoidance. Overall, the empirical results of this paper support the previous studies arguing the negative relationship between tax avoidance and CSR.
\end{abstract}

Keywords: Tax Avoidance; Corporate Social Responsibility; Book-Tax Differences

\section{INTRODUCTION}

(E) ince Scholes and Wolfson (1992) first show that managers have incentives to pursue tax strategy in a way that it minimizes corporate taxes in order to maximize firm's profit the number of studies have been done on tax strategy. As Zimmerman (1983) argues, however, minimizing taxes may not be always the most efficient tax strategy because it may occur additional costs (i.e. government regulations and auditing by nongovernment organization (NGO)). Thus, it is important to take into account specific corporate environments such as financing choices, corporate governance, tax-related laws, government policy, compensation policy, risk management decisions, and corporate social responsibility (here after, CSR) to see how taxes influence corporate financial decisionmaking (See Hanlon \& Heitzman (2010)). Even though the extensive research offers empirical evidence on such relationship between tax strategy and corporate environments, to knowledge there are few studies which examine how CSR affects managers' decision-making on taxes.

The objective of this study is to investigate how tax avoidance as one of tax strategies affects firms' CSR activities. In 2010 International Organization for Standardization (ISO) adopted ISO 26000 on Guidance for social responsibility. It implies that the stakeholders become increasingly aware of the need for and benefits of firms' social responsibilities, and accordingly they become one of crucial factors managers would consider for decision-making and management strategy.

Freedman (2003) argues that tax aggressiveness of firms with high CSR activities tends to occur additional costs due to high expectation and understanding of stakeholders on social responsibilities. Thus, it is expected for managers not to avoid taxes in order to reduce potential risks and induce disclosure effects of financial reporting. Watson (2011) also shows that firms with low CSR activities are more likely to be tax-aggressive because stakeholders of such firms are not surprised by socially irresponsible activities.

This study confirms the main findings of these two studies; the higher the level CSR of a corporation, the lower the level of tax avoidance. However, this study is different from Freedman (2003) and Watson (2011) in several points. First, Freedman (2003) offers only conceptual analysis the relationship, but does not provide empirical evidence. Even though Watson (2011) empirically tests the relationship between CSR values and tax avoidance, his empirical studies are limited to firms with low CSR activities. Second, this study employs different measurement of tax avoidance from one used by Watson (2011). While Watson introduces the unrecognized tax benefits (UTBs) as a proxy for tax 
aggressiveness, this study uses three different proxies to measure tax avoidance: residual book-tax differences (here after, BTD), year residual BTD and total BTD.

This study uses Korean Economic Justice Institute (KEJI) Index database. It provides social responsibility scores of publicly listed Korean firms on Korean Stock Exchange (KSE) in seven major categories: financial prudence, fairness and transparency, social services, consumer protection, protection of environments, satisfaction of employees, contributions to economic development for each firm-year. The sample contains 1,148 firm-year observations covering periods between 2004 and 2009.

This study finds that the negative relationship between the firm's CSR values and tax avoidance holds regardless which proxy of tax avoidance is used: The firms with higher CSR activities are less likely to avoid taxes. This finding is confirmed with two stage least square (2SLS) method after accounting for endogeneity of CSR. This paper also tests how seven different CSR activities affect tax avoidance. It finds that social services, satisfaction of employees and contributions to economic development are negatively related to tax avoidance.

The remainder of the paper is organized as follows. Section 2 provides previous literature. Section 3 develops the hypothesis of this paper. Section 4 describes the data and research design. Empirical results are reported and analyzed in Section 5. Section 6 concludes.

\section{THE PREVIOUS LITERATURE}

Zimmerman (1983) tests whether the firm's political costs as a proxy for firm size are associated with corporate tax rates. His study finds the positive relationship between them. He argues that larger size of firms tends to bear higher political costs and the corporate tax rates are one of a firm's political costs, and thus as the firm size gets larger the corporate tax rates becomes higher and the tax benefits would be smaller.

The study by Mills and Sansing (2000) is to examine how BTD affect the probability of auditing transaction and collecting additional taxes. Using Internal Revenue Service (IRS) data from the Coordinated Examination Program they find that the probability of auditing transaction by government increases as the a positive BTD exists due to the possibility of tax avoidance.

Plesko (2004) argues that the book-tax income spread provides tax authorities the information on adaptation to tax payment and investors better understanding on the quality of the book-tax spread. It, thus, implies that tax authorities and investors can make effective decision-making through the book-tax income spread and especially obtain the information on tax avoidance.

\section{HYPOTHESIS DEVELOPMENT}

For CSR behaviors to attract investors they should be able to reach not only maximization of economical values but also realization of proper social and ethical values. In order to achieve these two purposes CSR behaviors will be invested based on both financial and ethical criteria. CSR behaviors are one type of investment, not charity, but it would not be done by only financial purposes. It may be selected due to ethical reasons but may not be invested due to financial criteria.

From the aspect of financial criteria investors who prefer CSR activities may reduce uncertain risk because of low information asymmetry as they invest to firms with higher CSR activities. Thus, managers can reduce the cost of equity through CSR activities by satisfying stakeholders who want to reduce information asymmetry, and strategically accomplish the improvement of firm values and higher financial achievement (Ghoul, Guedhami, Kwok \& Mishra, 2010).

Tax investigation is one of firm's uncertain risks. Firms are levied huge penalties and additional taxes, and experience a decrease in work efficiency and legal trouble during the period of tax investigation. Firms with higher CSR activities, which reduce costs of equity by decreasing uncertain risks have higher additional opportunity costs on tax 
investigation than firms with lower CSR activities. Therefore, firms with higher CSR activities are more likely to be careful on tax investigation.

Manzon and Plesko (2002) argues that, the probability of tax investigation increases in the BTD. Mills and Sansings (2000) also show that collected additional taxes are larger as the BTD are bigger. Moreover, Plesko (2004) argues that the book-tax income spread provides tax authorities the information on adaptation to tax payment and investors better understanding on the quality of the book-tax spread, and thus tax authorities and investors can make effective decisionmaking through the book-tax income spread and especially obtain the information on tax avoidance.

All of these arguments imply that firms with higher CSR activities, wh+ich have greater uncertain risks are less likely to avoid taxes than firms with lower CSR activities. It provides us empirically testable hypothesis, Hypothesis 1.

H1: Corporate social responsibility activities are negatively related to tax avoidance.

Social responsibility scores of public Korean firms on Korean Stock Exchange (KSE) in seven major categories: financial prudence, fairness and transparency, social services, consumer protection, protection of environments, satisfaction of employees, contributions to economic development for each firm-year.

I also test how each individual seven factors of corporate social activities scores provided by KEJI Index dataset is associated with CSR activities. It provides seven following testable hypothesis.

H1(a): Financial prudence is negatively related to tax avoidance.

H1(b): Fairness and transparency are negatively related to tax avoidance.

H1(c): Social services are negatively related to tax avoidance.

H1(d): Consumer protection is negatively related to tax avoidance.

H1(e): Protection of environments is negatively related to tax avoidance.

H1(f): Satisfaction of employees is negatively related to tax avoidance.

H1(g): Contributions to economic development are negatively related to tax avoidance.

\section{RESEARCH DESIGN AND DESCRIBES THE DATA}

\subsection{Hypothesis Model}

As a try to examine whether the firm's CSR activities affect tax avoidance, I estimate regression model below:

$$
\begin{aligned}
& T S_{i t}=a_{0}+a_{1} C S R_{-} A_{i t}+a_{2} S I Z E_{i t}+a_{3} L E V_{i t}+a_{4} R O A_{i t}+a_{5} O C F_{i t}+a_{6} F O R_{i t}+a_{7} O W N_{i t}+ \\
& a_{8} M T B_{i t}+a_{9} B I G 4_{i t}+a_{10} R \& D_{i t}+\text { YearDummy }+ \text { IndDummy }+\varepsilon_{i t}
\end{aligned}
$$

where TS is a variable for BTD of each firm for each year. I use three different measures for this variable: residual BTD following Desai and Dharmapala (2006) (TS1), included year residual BTD following Koh (2007) (TS2), and total BTD. CSR_A is number of KEJI Index (Total CSR scores), a proxy for firm's CSR activities. KEJI has announced the index for the manufacturing corporates listed in the KSE. It is a score grounded on the evaluation of a corporate's performance activities using seven major categories with different weights: financial prudence, fairness and transparency, social services, consumer protection, protection of environments, satisfaction of employees, and contributions to economic development. SIZE is total assets, and enters as logarithm. $L E V$ is the ratio of total liabilities to total assets. $R O A$ is the return to assets. $O C F$ is operating cash flow to assets. FOR is ration to total stock and $O W N$ is ration to majority stock to total stock. MTB is market value to book value. Big4 is a dummy variable and it is 1 if a sample is a big 4 accounting firm, 0 otherwise. $R \& D$ is natural $\log$ of total $R \& D$ costs. Year Dummy and IndDummy are dummies for calendar year and K-SIC codes respectively.

Several studies investigate the relation between firm's characteristics and tax avoidance using a number of the proxies such as GAAP ETR, tax shelter and the BTDs (Hanlon \& Heitzman, 2010). I use the BTDs because BTDs provide information to the market (Hanlon, 2005). I also estimate equation (1) for each combination of three different BTDs and each CSR activities. 
The main focus of this study is the coefficient on CSR activities $\left(a_{1}\right)$. I expect a negative coefficient on the CSR activities variable when BTDs (residual, year residual book- and total) are used as measures of tax avoidance as mentioned in section 3 .

Also, I control for other factors harmonized with tax avoidance measures to investigate whether the CSR activities contribute to corporates' overall level of tax avoidance. Some study argues that economies of scale and firm complexity are harmonized with additional tax planning opportunities (e.g., Mills 1998; Koh 2007). Accordingly, I control for firm size (SIZE), leverage ( $L E V)$, firm profitability $(R O A)$, operating cash flow $(O C F)$ and growth opportunities $(M T B)$. In addition, I control for the big 4 accounting firms (BIG4), and Research \& Development $(R \& D)$ costs.

Besides controlling for known determinants of tax avoidance, I also include firms' levels of ownership $(O W N)$ and foreign ownership $(F O R)$. While the tax plan can have important implications for the development of corporate governance can have an important effect on tax avoidance (Desai \& Dharmapala, 2006; Koh, 2007)

I also test hypothesis 1 (a)-(g) using each individual seven index of corporate social activities provided by KEJI index to investigate the connection between corporate social activities and tax avoidance by equation (2).

$$
\begin{aligned}
& T S_{i t}=a_{0}+a_{1} C S R 1_{i t}+a_{2} C S R 2_{i t}+a_{3} C S R 3_{i t}+a_{4} C S R 4_{i t}+a_{5} C S R 5_{i t}+a_{6} C S R 6_{i t}+a_{7} C S R 7_{i t}+ \\
& a_{8} S I Z E_{i t}+a_{9} L E V_{i t}+a_{10} R O A_{i t}+a_{11} O C F_{i t}+a_{12} F_{10} R_{i t}+a_{13} O W N_{i t}+a_{14} M T B_{i t}+a_{15} B I G 4_{i t}+ \\
& a_{16} R \& D_{i t}+\text { YearDummy IndDummy }+\varepsilon_{i t}
\end{aligned}
$$

where $C S R 1_{i t}$ is financial prudence, $C S R 2_{i t}$ is fairness and transparency, $C S R 3_{i t}$ is social services, $C S R 4_{i t}$ is consumer protection, $C S R 5_{i t}$ is protection of environments, $C S R \sigma_{i t}$ is satisfaction of employees, and $C S R 7_{i t}$ is contributions to economic development of each sample for each year.

\subsection{Sample Selection}

This search for sample firms begins with firms that are included in KEJI 200 for the year 2004 through year 2009. In the step 2 I compute all variables used for the multivariate analyses. I have 1,800 observations to be merged with sample from step 1 after removing observations with missing values. The step 3 after requiring the necessary financial data disclosure on Kis-value as well as a matrix of control variables, also from Kis-value, reduces the sample size to 1,147 firms-years available for regression.

\section{RESULT}

\subsection{Univariate Analysis}

Table 1 provides descriptive statistics for the tax avoidance, CSR variables and control variables. In terms of TSI, the mean (median) is $0.009(0.005)$. I also find that the mean (median) for TS2 and TS3 are both $0.009(0.004)$. Given that both Tax avoidance measure have the same numerator. For CSR_A I observe that the mean (median) is 3.851 (3.860). Table 1 reports the descriptive statistics of each individual seven index CSR. CSR1 has a mean (median) of 2.719(2.733), CSR2 has a mean (median) of 2.130 (2.733), CSR3 has a mean (median) of 1.368 (1.329), CSR4 has a mean (median) of 1.197 (1.227), CSR5 has a mean (median) of 1.774 (1.740), CSR6 has a mean (median) 1.774 (1.722) and CSR7 has a mean (median) of 1.588 (1.598). 
Table 1. Descriptive Statistics

\begin{tabular}{|c|c|c|c|c|c|c|c|}
\hline & Mean & Std Dev & Min & 1st & Median & 3rd & Max \\
\hline TS1 & .009 & .042 & -.237 & -.007 & .005 & .021 & .306 \\
\hline$T S 2$ & .009 & .042 & -.239 & -.006 & .004 & .021 & .315 \\
\hline TS3 & .009 & .042 & -.240 & -.006 & .004 & .020 & .314 \\
\hline$C S R \_A$ & 3.860 & .051 & 3.775 & 3.821 & 3.851 & 3.892 & 4.046 \\
\hline CSR1 & 2.719 & .095 & 2.372 & 2.660 & 2.733 & 2.789 & 2.913 \\
\hline CSR2 & 2.130 & .099 & 1.696 & 2.048 & 2.158 & 2.214 & 2.327 \\
\hline CSR3 & 1.329 & .301 & .560 & 1.121 & 1.368 & 1.565 & 2.349 \\
\hline CSR4 & 1.197 & .119 & .811 & 1.100 & 1.227 & 1.247 & 1.589 \\
\hline CSR5 & 1.774 & .154 & 1.470 & 1.658 & 1.740 & 1.887 & 2.140 \\
\hline CSR6 & 1.706 & .224 & .971 & 1.559 & 1.722 & 1.875 & 2.163 \\
\hline CSR7 & 1.588 & .167 & 1.049 & 1.472 & 1.598 & 1.712 & 2.066 \\
\hline$S I Z E$ & 26.850 & 1.545 & 22.591 & 25.728 & 26.512 & 27.683 & 32.086 \\
\hline$L E V$ & -1.057 & .530 & -4.072 & -1.389 & -.956 & -.651 & .167 \\
\hline$R O A$ & .062 & .050 & -.326 & .032 & .056 & .088 & .359 \\
\hline$O C F$ & .077 & .078 & -.194 & .033 & .076 & .117 & .539 \\
\hline$F O R$ & 16.289 & 17.539 & .000 & 1.910 & 10.140 & 25.953 & 92.970 \\
\hline$O W N$ & 25.228 & 14.097 & .000 & 14.425 & 22.310 & 33.385 & 81.400 \\
\hline$M T B$ & .684 & .581 & .000 & .310 & .529 & .868 & 6.945 \\
\hline
\end{tabular}

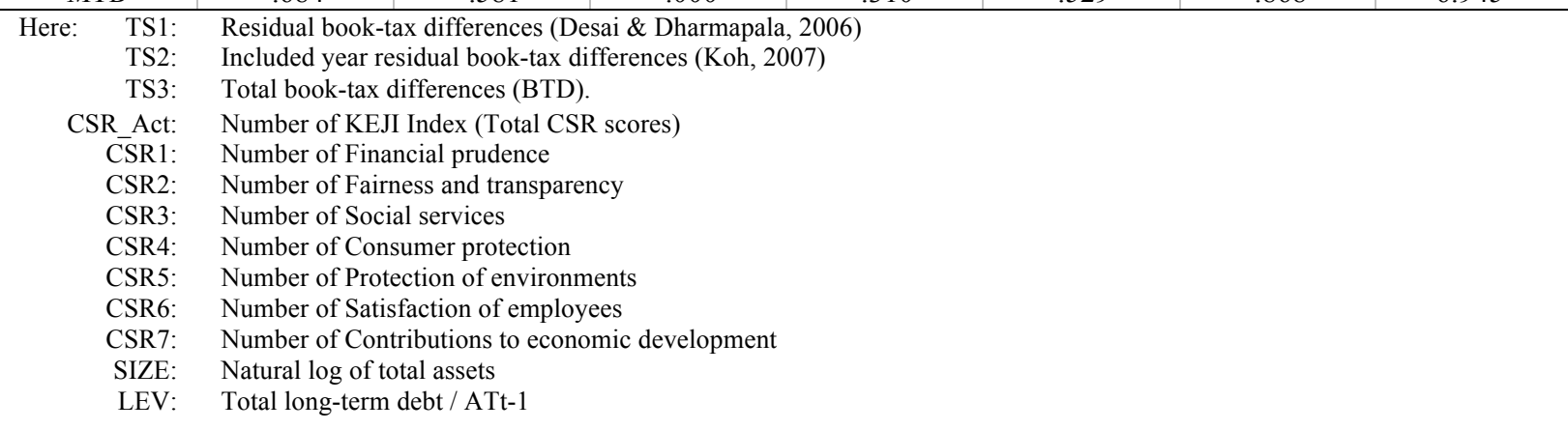

Table 2 presents correlations between measures of research regression model. Moreover, I also calculate variance in inflation factors (VIFs) when estimating research regression model 1 and model 2to test for signs of multi-collinearity among the explanatory variabels. This result confirm that no VIFs exceed twenty for any of explanatory variables, so multi-collinearity is not problematic in research regression model 1 and model 2. 
Table 2. Pearson Correlations

\begin{tabular}{|c|c|c|c|c|c|c|c|c|c|c|}
\hline & 1 & 2 & 3 & 4 & 5 & 6 & 7 & 8 & 9 & 10 \\
\hline 1. TS1 & 1 & $.993^{* *}$ & $.993^{* *}$ & .007 & $.058^{*}$ & $.069^{*}$ & -.036 & $.098^{* * *}$ & $.091^{* * *}$ & $-.182^{* *}$ \\
\hline 2. $T S 2$ & & 1 & $1.000^{* *}$ & .006 & .057 & $.068^{*}$ & -.042 & $.098^{* *}$ & $.089^{* *}$ & $-.174^{* *}$ \\
\hline 3. TS3 & & & 1 & .003 & .053 & $.067^{*}$ & -.043 & $.099^{* *}$ & $.088^{* *}$ & $-.172^{* *}$ \\
\hline 4. CSR_A & & & & 1 & $.449^{* *}$ & $.250^{* *}$ & $.393^{* *}$ & $.134^{* *}$ & $.333^{* *}$ & $.320^{* *}$ \\
\hline 5. CSR $\overline{1}$ & & & & & 1 & $-.070^{*}$ & $-.134^{* *}$ & -.002 & $-.087^{* *}$ & -.045 \\
\hline 6. CSR2 & & & & & & 1 & .000 & .045 & -.003 & $-.090^{* *}$ \\
\hline 7. $C S R 3$ & & & & & & & 1 & $-.096^{* *}$ & .014 & -.023 \\
\hline 8. CSR4 & & & & & & & & 1 & $.259^{* *}$ & $-.188^{* *}$ \\
\hline 9. CSR5 & & & & & & & & & 1 & $-.199^{* *}$ \\
\hline 10. CSR6 & & & & & & & & & & 1 \\
\hline
\end{tabular}

\begin{tabular}{|c|c|c|c|c|c|c|c|c|c|c|}
\hline & 11 & 12 & 13 & 14 & 15 & 16 & 17 & 18 & 19 & 20 \\
\hline 1. TS1 & .038 & $.083^{* *}$ & $-.075^{*}$ & $.397^{* *}$ & $.201^{* *}$ & -.028 & -.011 & .046 & $.070^{*}$ & -.048 \\
\hline 2. $T S 2$ & .039 & $.075^{*}$ & $-.073^{*}$ & $.404^{* *}$ & $.207^{* *}$ & -.031 & -.011 & .046 & $.067^{*}$ & -.047 \\
\hline 3. $T S 3$ & .038 & $.072^{*}$ & $-.074^{*}$ & $.409^{* *}$ & $.187^{* *}$ & -.032 & -.011 & .044 & $.065^{*}$ & -.047 \\
\hline 4.CSR_A & $.444^{* *}$ & $.347^{* *}$ & $-.065^{*}$ & $.235^{* *}$ & $.252^{* *}$ & $.249^{* *}$ & $-.059^{*}$ & $.201^{* *}$ & $.336^{* *}$ & .037 \\
\hline 5.CSR $\overline{1}$ & .017 & $.090^{* *}$ & $-.269^{* *}$ & $.217^{* *}$ & $.247^{* *}$ & $.210^{* *}$ & $-.061^{*}$ & $.134^{* *}$ & $.259^{* *}$ & -.023 \\
\hline 6.CSR2 & -.018 & $.077^{* *}$ & .037 & .043 & $.069^{*}$ & -.026 & $.075^{*}$ & $.074^{*}$ & .020 & .014 \\
\hline 7.CSR 3 & $.074^{*}$ & $.151^{* *}$ & .027 & $.066^{*}$ & .057 & .018 & .035 & .026 & .016 & .035 \\
\hline 8.CSR4 & .001 & $.145^{* *}$ & .019 & -.037 & -.046 & .012 & -.051 & $.080^{* *}$ & -.055 & -.012 \\
\hline 9.CSR5 & $.183^{* *}$ & $.445^{* *}$ & $.079^{* *}$ & -.006 & .035 & $.194^{* *}$ & -.055 & $.082^{* *}$ & -.019 & -.032 \\
\hline 10. CSR6 & -.011 & $-.157^{* *}$ & $.116^{* *}$ & -.055 & $-.079^{* *}$ & -.001 & -.011 & -.003 & $.128^{* *}$ & .033 \\
\hline 11.CSR7 & 1 & $.226^{* *}$ & $-.070^{*}$ & $.297^{* *}$ & $.248^{* *}$ & $.168^{* *}$ & $-.075^{*}$ & $.125^{* *}$ & $.329^{* *}$ & $.086^{* *}$ \\
\hline 12.SIZE & & 1 & $.314^{* *}$ & $.069^{*}$ & $.135^{* *}$ & $.424^{* *}$ & $-.104^{* *}$ & $.304^{* *}$ & $.130^{* *}$ & -.036 \\
\hline 13.LEV & & & 1 & $-.248^{* *}$ & $-.142^{* *}$ & -.035 & -.018 & $.108^{* *}$ & $-.198^{* *}$ & .012 \\
\hline 14. ROA & & & & 1 & $.420^{* *}$ & $.210^{* *}$ & $.081^{* *}$ & $.079^{* *}$ & $.377^{* *}$ & -.040 \\
\hline 15.OCF & & & & & 1 & $.143^{* *}$ & .046 & $.113^{* *}$ & $.311^{* *}$ & -.019 \\
\hline 16.FOR & & & & & & 1 & .020 & $.199^{* *}$ & $.298^{* *}$ & .005 \\
\hline 17. OWN & & & & & & & 1 & $.066^{*}$ & -.007 & .018 \\
\hline 18.BIG4 & & & & & & & & 1 & $.129^{* *}$ & $-.073^{*}$ \\
\hline 19.MTB & & & & & & & & & 1 & -.013 \\
\hline $20 . R \& D$ & & & & & & & & & & 1 \\
\hline
\end{tabular}

1) This table presents the Pearson Correlations among main variables

2) *** represent $5 \%$ and $1 \%$ level significantly respectively

\subsection{Regression Results}

To examine the tax avoidance of CSR, I regress the tax avoidance on various CSR proxies and control variables using multivariate regression. Table 3, Table 4 and Table 5 reports the regression results for the research model 1 and model 2. Table 3, Table 4 and Table 5 show that the regression coefficient for CSR_A is negative and significantly associated with tax avoidance $(\mathrm{P}<0.01)$, support for hypothesis 1 . Accordingly, CSR activities are negatively related to tax avoidance.

Table 3, Table 4 and Table 5 also show relate individual seven CSR components and tax avoidance. In this table, CRS3 (social services), CSR6 (satisfaction of employees) and CSR7 (contributions to economic development) activities are significantly negatively related to tax avoidance. This result support hypothesis 1 , too.

The other hand, the regression for CSR1 (financial prudence), CSR2 (fairness and transparency) and CSR4 (consumer protection) are not significantly related to tax avoidance. These finding suggest that CSR activities components CSR1 (financial prudence), CSR2 (fairness and transparency) and CSR4 (consumer protection) do not affect tax avoidance. 
One puzzling regression result is the coefficient on CSR5 (protection of environments), which loads significantly in a positive direction. It is only coefficient that is statistically significant in a positive direction. This suggests that CSR5 (protection of environments) is associated with tax avoidance.

To summarize, three main result emerge from the analysis in Table 3, Table 4 and Table 5. First, CSR activity is associated tax avoidance. Second, the only CSR components that negatively affect tax avoidance are CSR3 (social services), CSR6 (satisfaction of employees) and 7(contributions to economic development). Third CSR5 (protection of environments) have positively significantly tax avoidance.

Table 3. Result of Hypothesis 1 (by using Desai \& Dharmapala (2006)' measure)

\begin{tabular}{|c|c|c|c|c|c|c|}
\hline \multirow{2}{*}{ Variable } & \multicolumn{6}{|c|}{ TS1(residual book-tax differences (Desai \& Dharmapala, 2006) } \\
\hline & Coeff. & t-stat. & VIF & Coeff. & t-stat. & VIF \\
\hline Intercept & 0.178 & $1.861^{*}$ & & -0.005 & 0.055 & \\
\hline CSR_A & -0.069 & $-2.639^{* * *}$ & 1.473 & & & \\
\hline CSR $\bar{l}$ & & & & -0.009 & -0.647 & 1.368 \\
\hline CSR2 & & & & 0.006 & 0.527 & 1.066 \\
\hline CSR3 & & & & -0.006 & -1.519 & 1.193 \\
\hline CSR4 & & & & 0.008 & 0.807 & 1.193 \\
\hline CSR5 & & & & 0.015 & $1.665^{*}$ & 1.741 \\
\hline CSR6 & & & & -0.012 & $-2.104^{* *}$ & 1.416 \\
\hline CSR7 & & & & -0.039 & $-4.691^{* * *}$ & 1.674 \\
\hline SIZE & 0.003 & $3.317^{* * *}$ & 1.803 & 0.002 & $2.150^{* *}$ & 2.343 \\
\hline$L E V$ & -0.002 & -0.797 & 1.335 & -0.001 & -0.251 & 1.470 \\
\hline$R O A$ & 0.367 & $14.235^{* * *}$ & 1.410 & 0.387 & $14.817^{* * *}$ & 1.475 \\
\hline$O C F$ & 0.023 & 1.451 & 1.328 & 0.025 & 1.511 & 1.372 \\
\hline FOR & -0.033 & $-4.382^{* * *}$ & 1.434 & -0.033 & $-4.458^{* * *}$ & 1.460 \\
\hline$O W N$ & -0.016 & $-1.950^{*}$ & 1.065 & -0.017 & $-2.181^{* *}$ & 1.090 \\
\hline$M T B$ & -0.003 & -1.122 & 1.499 & 0.000 & 0.103 & 1.617 \\
\hline$B I G 4$ & 0.002 & 0.584 & 1.228 & 0.002 & 0.770 & 1.244 \\
\hline$R \& D$ & -0.001 & -0.439 & 1.036 & 0.001 & 0.280 & 1.060 \\
\hline Year_D & \multicolumn{6}{|c|}{ Yes } \\
\hline Industry_D & \multicolumn{6}{|c|}{ Yes } \\
\hline Adj. $R^{2}$ & \multicolumn{3}{|c|}{0.226} & \multicolumn{3}{|c|}{0.243} \\
\hline F-value & \multicolumn{3}{|c|}{19.650} & \multicolumn{3}{|c|}{16.345} \\
\hline
\end{tabular}

1) $* * *, * * *$ represent $10 \%, 5 \%$ and $1 \%$ level significantly respectively 
Table 4. Result of Hypothesis 1 (by using Koh (2007)' measure)

\begin{tabular}{|c|c|c|c|c|c|c|}
\hline \multirow{2}{*}{ Variable } & \multicolumn{6}{|c|}{ TS2 (included year residual book-tax differences $(\mathrm{Ko}, 2007)$} \\
\hline & Coeff. & t-stat. & VIF & Coeff. & t-stat. & VIF \\
\hline Intercept & 0.189 & $1.978^{*}$ & & 0.003 & 0.049 & \\
\hline$C S R \_A$ & -0.070 & $-2.656^{* * *}$ & 1.473 & & & \\
\hline CSR 1 & & & & -0.009 & -0.655 & 1.368 \\
\hline CSR2 & & & & 0.006 & 0.527 & 1.066 \\
\hline CSR3 & & & & -0.007 & $-1.681^{*}$ & 1.193 \\
\hline CSR4 & & & & 0.009 & 0.881 & 1.193 \\
\hline CSR5 & & & & 0.016 & $1.693^{*}$ & 1.741 \\
\hline CSR6 & & & & -0.011 & $-1.981^{* *}$ & 1.416 \\
\hline CSR7 & & & & -0.040 & $-4.794^{* * *}$ & 1.674 \\
\hline SIZE & 0.003 & $2.979^{* * *}$ & 1.803 & 0.002 & $1.893^{*}$ & 2.343 \\
\hline$L E V$ & -0.001 & -0.564 & 1.335 & 0.000 & -0.041 & 1.470 \\
\hline$R O A$ & 0.375 & 14.534 & 1.410 & 0.396 & $15.158^{* * *}$ & 1.475 \\
\hline$O C F$ & 0.027 & 1.642 & 1.328 & 0.028 & $1.726^{*}$ & 1.372 \\
\hline FOR & -0.032 & $-4.355^{* * *}$ & 1.434 & -0.033 & $-4.443^{* * *}$ & 1.460 \\
\hline$O W N$ & -0.016 & $-2.012^{*}$ & 1.065 & -0.018 & -2.238 & 1.090 \\
\hline$M T B$ & -0.003 & -1.216 & 1.499 & 0.000 & 0.006 & 1.617 \\
\hline$B I G 4$ & 0.002 & 0.671 & 1.228 & 0.002 & 0.851 & 1.244 \\
\hline$R \& D$ & -0.001 & -0.435 & 1.036 & 0.001 & 0.301 & 1.060 \\
\hline Year_D & \multicolumn{6}{|c|}{ Yes } \\
\hline Industry_D & \multicolumn{6}{|c|}{ Yes } \\
\hline Adj. $\mathrm{R}^{2}$ & \multicolumn{3}{|c|}{0.232} & \multicolumn{3}{|c|}{0.250} \\
\hline F-value & \multicolumn{3}{|c|}{20.290} & \multicolumn{3}{|c|}{16.910} \\
\hline
\end{tabular}

Table 5. Result of Hypothesis 1 (by using BTD)

\begin{tabular}{|c|c|c|c|c|c|c|}
\hline \multirow{2}{*}{ Variable } & \multicolumn{6}{|c|}{ TS3 (total book-tax differences) } \\
\hline & Coeff. & t-stat. & VIF & Coeff. & t-stat. & VIF \\
\hline Intercept & 0.190 & $1.989^{*}$ & & 0.004 & 0.067 & \\
\hline$C S R \_A$ & -0.070 & $-2.666^{* * *}$ & 1.473 & & & \\
\hline CSR $\overline{1}$ & & & & -0.009 & -0.674 & 1.368 \\
\hline CSR2 & & & & 0.006 & 0.512 & 1.066 \\
\hline CSR3 & & & & -0.007 & $-1.690^{*}$ & 1.193 \\
\hline CSR4 & & & & 0.009 & 0.884 & 1.193 \\
\hline CSR5 & & & & 0.016 & $1.703^{*}$ & 1.741 \\
\hline CSR6 & & & & -0.011 & $-1.977^{* *}$ & 1.416 \\
\hline CSR7 & & & & -0.040 & $-4.785^{* * *}$ & 1.674 \\
\hline SIZE & 0.003 & $2.979^{* * *}$ & 1.803 & 0.002 & $1.888^{*}$ & 2.343 \\
\hline$L E V$ & -0.001 & -0.570 & 1.335 & 0.000 & -0.051 & 1.470 \\
\hline$R O A$ & 0.389 & $15.090^{* * *}$ & 1.410 & 0.410 & $15.706^{* *}$ & 1.475 \\
\hline$O C F$ & 0.012 & 0.731 & 1.328 & 0.013 & 0.822 & 1.372 \\
\hline FOR & -0.032 & $-4.363^{* * *}$ & 1.434 & -0.033 & $-4.451^{* * *}$ & 1.460 \\
\hline$O W N$ & -0.016 & $-2.009^{* *}$ & 1.065 & -0.018 & $-2.234^{* * *}$ & 1.090 \\
\hline$M T B$ & -0.003 & -1.206 & 1.499 & 0.000 & 0.012 & 1.617 \\
\hline$B I G 4$ & 0.002 & 0.661 & 1.228 & 0.002 & 0.841 & 1.244 \\
\hline$R \& D$ & -0.001 & -0.437 & 1.036 & 0.001 & 0.298 & 1.060 \\
\hline Year_D & \multicolumn{6}{|c|}{ Yes } \\
\hline Industry_D & \multicolumn{6}{|c|}{ Yes } \\
\hline Adj. $\mathrm{R}^{2}$ & \multicolumn{3}{|c|}{0.235} & \multicolumn{3}{|c|}{0.252} \\
\hline F-value & \multicolumn{3}{|c|}{20.554} & \multicolumn{3}{|c|}{17.107} \\
\hline
\end{tabular}

$1)^{*}, * *, * * *$ represent $10 \%, 5 \%$ and $1 \%$ level significantly respectively 


\section{CONCLUSION}

This study examines whether CSR activity affects tax avoidance. I contend that CSR activities are negatively related to tax avoidance. Using a sample of 1,477 Korean firms-year observations from 2004 to 2009 and controlling for other firm-specific determinants as well as industry and year fixed effects, I find that firms with CSR activity significantly associated with lower tax avoidance. The empirical results are consistent with hypothesis. Moreover, I find that not all individual seven CSR components are related to tax avoidance. In particular, while CRS activities for social services, satisfaction of employees and contributions to economic development contribute to lowering tax avoidance, CSR activities for financial prudence, fairness and transparency and consumer protection do not. This study contributes to examine how CSR affects managers' decision-making on taxes.

\section{AUTHOR BIOGRAPHIES}

SungJong Park (author) is an associate professor of Dept. of Global Business Administration at Anyang University in Korea. Research interests include tax, IFRS and auditing. E-mail: sjpark@anyang.ac.k

\section{REFERENCES}

Desai, M., \& D. Dharmapala (2006). Corporate tax avoidance and high powered incentives. Journal of Financial Economics, $79,145-179$.

Freedman, J. (2003). Tax and corporate responsibility. Tax Journal, 695(2), 1-4.

Friedman, M. (1970). Social responsibility of business. New York Times Magazine

Ghoul. S., Guedhami. O, Kwok, and Y, Mishra, Dev (2010). Does corporate social responsibility affect the cost of capital? working paper

Hanlon, M. (2005). The persistence and pricing of earnings, accruals, and cash flows when firms have large book-tax differences. Journal of Accounting Review, 80(1), 137-166.

Hanlon, M. \& Heitzman, S. (2010). A review of tax research. Journal of Accounting \& Economics, 50, 127-178.

Koh. (2007). A study on corporate tax avoidance. Korean Journal of Taxation Research, 24(4), 9-40.

Manzon, G., \& G. A. Plesko (2002). The relation between financial and tax reporting measures of income. Tax Law Review, 55(2): $175-214$.

Mills. L. \& R. Sansing. (2000). Strategic tax and financial reporting decisions: Theory and evidence. Contemporary Accounting Research, 17, 85-106.

Mills. L. (1998). Book-tax differences and Internal Revenue Service adjustments. Journal of Accounting Research, 28, $343-356$.

Plesko, G. (2004). Corporate tax avoidance and the properties of corporate earnings. National Tax Journal, 57(3),729-738.

Scholes, M. \& M. Wolfson (1992). Taxes and business strategy: A planning approach. Prentice Hall.

Watson, L. (2011). Corporate social responsibility and tax aggressiveness: An examination of unrecognized tax benefits. Working paper.

Zimmerman, J. L. (1983). Tax and firm size. Journal of Accounting and Economics, 5,119-149. 


\section{APPENDIX}

KEJI Index (disclosure items)

\begin{tabular}{|c|c|c|}
\hline Evaluation Criteria & $\begin{array}{ll}\text { Evaluation Index } \\
\end{array}$ & Score \\
\hline \multirow{4}{*}{$\begin{array}{l}\text { Financial prudence } \\
(\mathrm{CSR} 1)\end{array}$} & Prudence of organization of shareholders & 12 \\
\hline & Prudence of Investment & 3 \\
\hline & Prudence of financing & 10 \\
\hline & Tax evasion & - \\
\hline \multirow{4}{*}{$\begin{array}{l}\text { Fairness and transparency } \\
\text { (CSR2) }\end{array}$} & Fairness & 5 \\
\hline & Transparency & 8 \\
\hline & Cooperative relation & 2 \\
\hline & Holding stakes of press and financial institutions & - \\
\hline \multirow{2}{*}{$\begin{array}{l}\text { Social services } \\
\text { (CSR3) }\end{array}$} & Protection of the neglected & 6 \\
\hline & Contribution to society & 4 \\
\hline \multirow{3}{*}{$\begin{array}{l}\text { Consumer protection } \\
\text { (CSR4) }\end{array}$} & Consumer right protection & 5 \\
\hline & Product quality & 3 \\
\hline & Advertisement & 2 \\
\hline \multirow{3}{*}{$\begin{array}{l}\text { Protection of environments } \\
\text { (CSR5) }\end{array}$} & Effort to environmental improvement & 7 \\
\hline & Being environmental-friendly & 3 \\
\hline & Violation and pollution records & 5 \\
\hline \multirow{6}{*}{$\begin{array}{l}\text { Satisfaction of employees } \\
\text { (CSR6) }\end{array}$} & Health care and Security in Work places & 2 \\
\hline & Investment on human capital & 4 \\
\hline & Wages and employment welfare & 4 \\
\hline & Labor relations & 2 \\
\hline & Sex discrimination & 3 \\
\hline & Cooperation of labor and managers & - \\
\hline \multirow{2}{*}{$\begin{array}{l}\text { Contributions to economic } \\
\text { development } \\
\text { (CSR7) }\end{array}$} & Research and development (R\&D) & 3 \\
\hline & Management performance and contributions to economic development & 7 \\
\hline $\begin{array}{l}\text { Total } \\
\text { (KEJI) }\end{array}$ & & 100 \\
\hline
\end{tabular}

